\title{
地震動を想定した動的不規則荷重下における 枠組壁工法耐力壁の面内せん断性状及び減衰係数に関する研究 STUDY ON SHEAR PROPERTIES AND DAMPING COEFFICIENT OF
WOODEN BEARING WALL IN DYNAMIC RANDOM LOAD ASSUMING SEISMIC MOTION
}

金子大希*，野口弘行**

Daiki KANEKO and Hiroyuki NOGUCHI

\begin{abstract}
The purpose of this study is to reveal the shear properties and evaluate the damping coefficient of the wooden bearing wall. Since a recent idea of "seismic performance design method" has come to be required in timber structure. And therefore "time history calculation" and "limit strength calculations" are needed even in timber structure. However, the data of the timber structure to their calculation is insufficient. So by fulfilling the above object, we want to allow those calculations in wooden bearing wall, and hopes to improve the seismic design accuracy of timber structure.
\end{abstract}

Keywords: Timber structure, Wooden bearing wall, Dynamic random load, Shear properties, Damping coefficient 木質構造, 木質而力壁, 動的不規則荷重, 面内せん断性状, 減衰係数

\section{1. はじめに}

2009 年に長期優良住宅認定制度が導入され、木質構造住宅におい ても『性能規定型設計』1)による耐震設計が求められている。『性能 規定型設計』では、より正確に構造物の地震応答を予測する必要が あり、構造計算では時刻歴応答解析や限界耐力計算などを用いるこ とが推奨されている。しかしながら現状では、木質構造住宅におい て時刻歴応答解析や限界耐力計算が行われることは皆無であり、耐 震等級 II 以上を確保する方法がとられてきた。より地震応答を正確 に予測するために、今後これらの構造計算が木質構造住宅において も取り入れていくことは重要と考える。時刻歴応答解析や限界耐力 計算は、構造物の動的挙動が強く反映された計算である。構造物の 動的挙動は減衰を重要な指標の一部として評価することが多いため 木質構造物においても減衰を正確に評価することが重要となる。し かし木質構造物は、 $\mathrm{S}$ 造や RC 造のように減衰に関する資料 2)が整 理されていないため、木質構造物においてもそのような資料を得る ことは早急に必要であろう。木質構造物の構造設計では最小構造要 素として木質耐力壁（以下耐力壁）を用いることが多いため、『性能 規定型設計』への移行に伴い耐力壁の動的挙動に関する研究が様々 な研究者によって行われ始めた。耐力壁の動的挙動に関寸る研究の 一つに面内せん断性状(以下せん断性状と呼ぶ) に関する研究がある。 せん断性状は面内せん断試験における荷重変形曲線の包絡線から得 られる初期剛性、降伏点、最大荷重点、終局点、塑性率（以下まと めて基本性能と呼ぶ）より検討されることが一般的である。しかし
前述した $2 つ の$ 構造計算では基本性能のみならず荷重変形曲線の履 歴性状(エネルギー吸収量など)も重要な指標となっているため、履 歴性状を耐力壁のせん断性状の指標の一部として静的及び動的の違 いを比較検証することは大変有効と考える。そのような研究を行っ た論文に西村ら 3)、綿引ら 4)、山口ら 5)、梶川ら 6)、内山ら 7)、等が ある。山口ら及び内山らは耐力壁の力学モデルを減衰係数一定とし た Voigt 型モデルとし、静的及び動的速度の単調引張載荷試験を行 うことで、耐力壁の減衰係数を算出することを試みている(本論にお いても採用した方法である)。結論は耐力壁の実挙動は、上記のよう な単純な Voigt 型モデルで表すことは難しいと報告している。しか し時刻歷応答解析や限界耐力計算を行うためには耐力壁の減衰の指 標を与える必要がある。筆者らは、静的及び動的載荷におけるせん 断性状の差異の細かな要因は追及せず、大局的に減衰を評価するこ とで、両載荷でのエネルギー吸収量を等価にするための減衰係数を 評価することを考えた。そこで、ある程度実挙動を想定した静的及 び動的速度の不規則載荷試験を行うことで、耐力壁のせん断性状に ついて検討し、さらに山口ら及び内山らと同様の理論を用い耐力壁 の減衰係数を大局的に定量評価することを試みた。尚、対象の耐力 壁の工法は内山らの研究との比較も考え枠組壁工法とした。本論の 目的を以下に記す。

動的不規則荷重下における枠組壁工法耐力壁のせん断性状を分析 し、減衰係数を定量評価する。尚、本論文の一部は文献 8)で発表し ている。
* 明治大学大学院博士前期課程

** 明治大学理工学部建築学科 教授. 工博
Grad. Stud., Dept. of Architecture, Graduate School of Science Technology, Meiji Univ. Prof., Dept. of Architecture, School of Science and Technology, Meiji Univ., Dr. Eng. 


\section{2. 面内せん断試験}

\section{1 試験体}

試験体は、枠組壁工法建築物構造計算指針 9)に準ずる仕様を基に した幅 $910 \mathrm{~mm}$ ・高さ $2578 \mathrm{~mm}$ の耐力壁である。Fig.1 に概要を示 す。枠材は” $2 \times 4$ ”材 $(\mathrm{SPF}$ 等級)を用い、@ 455 で配置したたて枠 を上下枠に 2-CN90E で取り付けた。ただし、柱脚部での破壊を完 全に除去するために耐力壁両側の枠材は 2 本とし、それぞれ CN90F-@200千鳥で取り付けた。上枠は加力桁材(無等級米栂 $89 \times$ 178)に、下枠は土台材(無等級米栂 $89 \times 90)$ にそれぞれ 2-M16(土台 側はアンカーボルト)とラグスクリュー10-M8 で緊結した。この枠 材に 2 級構造用合板 $9 \mathrm{~mm}$ (針葉樹)の面材を CN50-@200(内外周共) によって取り付けた。また偏心による忘力のばらつきを小さくする ため、合板は両面張りとした。また両側のたて枠と上枠には羽子板 ボルトM12、下枠にはホールダウン金物 HD-25(M16)によって枠材 同士の離れを防止した。試験体数は 6 波の地震波 $(1$ 波につき動的 $\times$ 1、静的×3)と規則波 3 体の計 27 体とした。

\section{2 測定方法}

計測ソフトは東京測器研究所社製の動ひずみデータ収録ソフト 「Hakaro」を使用し、計測記録器は「DRA-101C」を使用した。得 られるアナログデータは DRA-101C、GPIB-USBを介し、パーソナ ルコンピュータにデジタルデータとして記録した。Fig.2 に計測機 器配置図を示す。変位は変位計 $\delta 1$ 、荷重、加速度は載荷装置先端に 取り付けた荷重計及び加速度計で計測し、水平右向き及び鉛直上向 きをそれぞれ正方向とした。その他にも壁の挙動及び管理用として $\delta 2 \sim \delta 5$ 、そして試験治具の計測も行った。

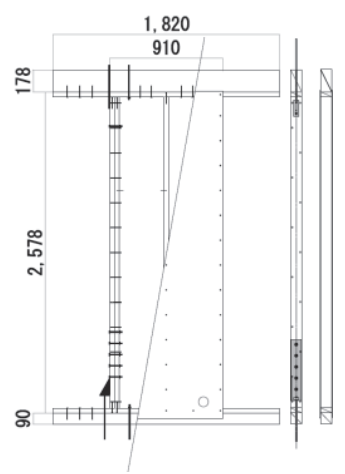

Fig. 1 Test body

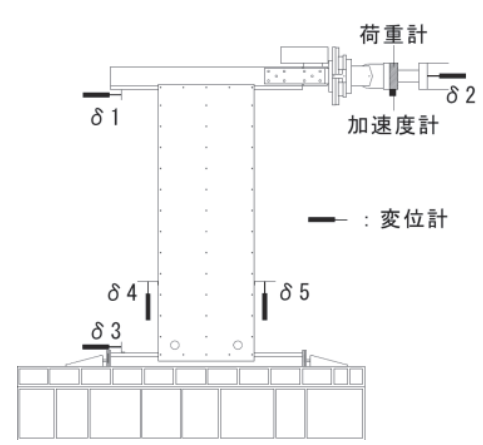

Fig. 2 Measuring instrument

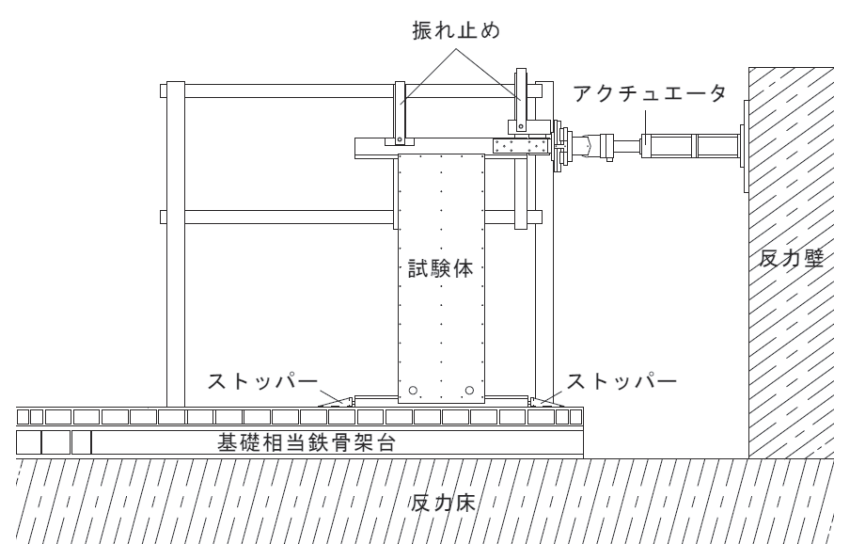

Fig. 3 Testing equipment

\section{3 試験装置}

無積載柱脚固定起立型で試験体頂部に強制変位を与える方法とし た(Fig.3)。載荷装置には株式会社鷺宮製作所製による油圧式 $200 \mathrm{kN}$ 動的載荷試験機(以下載荷装置)を使用した。載荷装置と試験体は口 ーラー・回転機構を持つ治具を挟み、M24 ボルト 5 本で緊結した。 また、面外方向に変形しないよう加力桁 2 箇所に振れ止めを設置し た。振れ止めと試験体の設置部分には車輪を設け、面内方向におい ては滑らかに変形できるようにした。試験体の浮き上がりについて は、両たて枠材の柱脚部に取り付けたホールダウン金物及び、試験 体の下枠・土台に空けた貫通穴(計 2 箇所)から M16 ボルトを通し、 それぞれ基礎相当の鉄骨架台と $2 \mathrm{kN}$ の張力をかけて拘束した。試験 体の水平移動は土台両端のストッパーによって固定した。

\section{4 入力波}

動的及び静的載荷で同変位履歴を入力することを考え、挙動の変 化が速度のみに依存するようにした。動的載荷で入力する変位は、 耐力壁 1 枚のモデルを Newmarc $\beta$ 法で時刻歴応答計算することで 得られる応答変位の時刻歴である。モデルは同試験体の静的正負交 番繰り返し載荷のデータから作成したバイリニアとスリップの足し 合わせによる弾塑性モデルである。また、地震波毎にモデルの質量 を調整し、応答計算結果の最大応答変形が $1 / 50 \mathrm{rad}$ 程度になるよう にした。減衰係数は $1052 \mathrm{~N} \cdot \mathrm{s} / \mathrm{m}$ （本研究室での検討值）とした。 用いた地震波計 6 波は Table1 に示す通りである。Fig.4 に時刻歴応 答計算で得た応答変位の時刻歴(灰色線)を示す。静的載荷では以上 の動的試験で計測された変位を一定速度 $0.1 \mathrm{~mm} / \mathrm{s}$ で載荷装置に入 力することで、動的試験と同変位履歴を与えた。静的試験は膨大な 載荷時間を費やすため地震初期から主要な大変形まで(Fig.4 黒色線 部,動的試験の検討もこの区間のデータのみ用いた)について実施し た。さらに不規則挙動と比較するべく一般的な載荷方法と同様変形 角が $1 / 450 、 1 / 300 、 1 / 200 、 1 / 150 、 1 / 100 、 1 / 75 、 1 / 50 \mathrm{rad}$ の正負交 番繰り返し 3 回載荷(規則載荷と定義する)による静的試験も行った。

Table1 Seismic wave summary

\begin{tabular}{|c|c|c|c|c|c|c|}
\hline 地震名 & 地震波形 & 略称 & 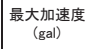 & $\begin{array}{l}\text { 啠量 } \\
(\mathrm{kg})\end{array}$ & $\begin{array}{c}\text { 弾性固有周期 } \\
(\mathrm{s})\end{array}$ & $\mid \begin{array}{c}\text { ベースシア係数 } \\
\text { (降伏点) }\end{array}$ \\
\hline 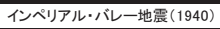 & エルセントロ1940-NS & EICentro & 341.7 & 1716 & 0.48 & 0.37 \\
\hline 兵庫県南部地震 (1995) & JMAKOBE-NS & Kobe & 231.6 & 1389 & 0.43 & 0.46 \\
\hline 十勝沖地震 (1968) & 八戸1968-NS & Hachinohe & 229.7 & 3366 & 0.67 & 0.19 \\
\hline 宮城県沖地震 (1978) & 東北1978-NS & Tohoku & 258.1 & 1425 & 0.43 & 0.45 \\
\hline 新渴中越地震 (2004) & NIG019-NS(K-NET) & Nigata & 1139.3 & 537 & 0.27 & 1.18 \\
\hline 告示波※ & - & Takahashi & 293.0 & 1713 & 0.47 & 0.37 \\
\hline
\end{tabular}

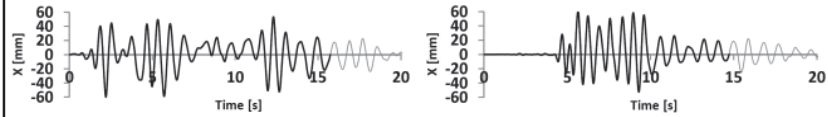

(a) ElCentro

(b) Kobe

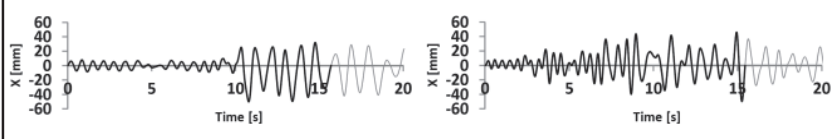

(c) Hachinohe

(d) Tohoku

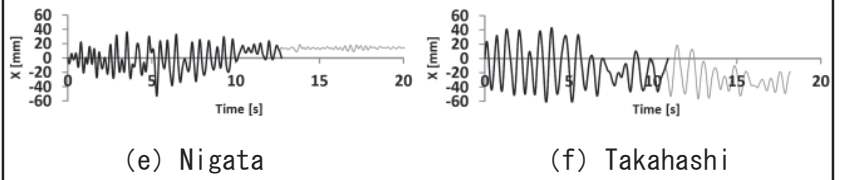

Fig. 4 Response displacement after the calculation 


\section{3. 試験結果}

動的載荷での荷重 $v P$ は荷重計 $P$ の值から試験体半分の質量と試 験治具質量の和に加速度を乗じて算出した慣性力を引いた值とした $\left({ }_{v} P=P-M \ddot{x}\right)$ 。これは、6 章以降の検討において荷重変形曲線の荷重 $P$ を耐力壁の内部抵抗力 $Q$ (内力) として扱うためである。また各計 測器で得られたデータはローパスフィルター $(20 \mathrm{~Hz}$ 程度)による平 滑加工を行った。そして Fig.5 に以上の処理を加えた動的(dynamic) 及び静的(static)載荷における荷重変形曲線を、そして Fig.6 に静的 試験での不規則(Random)及び規則(Regular)載荷における荷重変形 曲線を示した。静的試験での荷重変形曲線は 3 体行ったうちの 1 つ を代表して示した。

Fig.5 より、動的及び静的載荷での荷重変形曲線で概形が大きく 変わることはないといえよう。

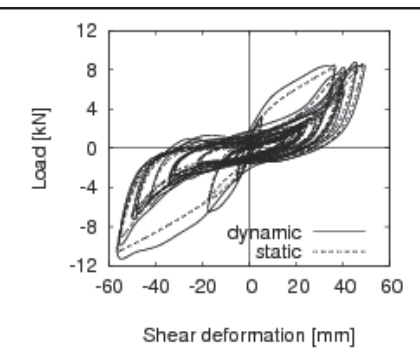

(a) ElCentro

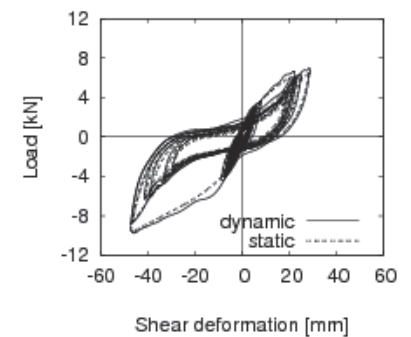

(c) Hachinohe

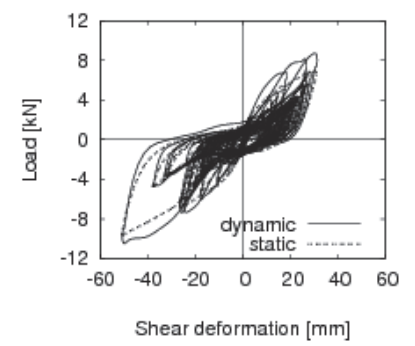

(e) Nigata

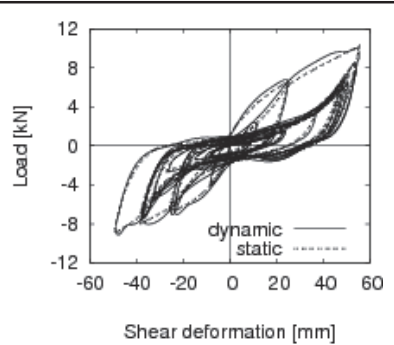

(b) Kobe

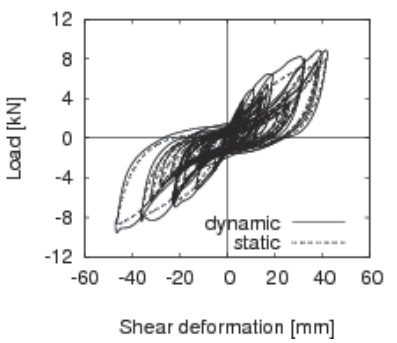

(d) Tohoku

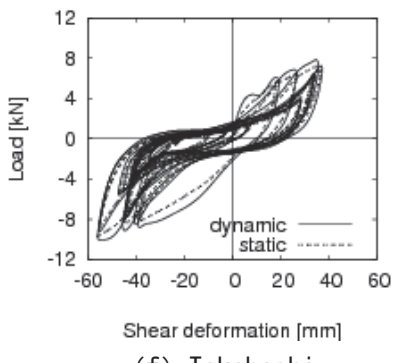

(f) Takahashi
Fig. 5 Relation of $P \& x$ [dynamic \& static]
また Fig.6 より、不規則及び規則載荷での荷重変形曲線において も入力変位が異なるため履歴曲線の形は異なるものの、概形は大き く変化しないといえよう。

ここで、各荷重変形曲線での包絡線から特定変形角時における荷 重を算出し Table2 に示した。特定変形角時の荷重は正負それぞれ の平均で算出し、地震波においては変形角毎に動的、静的それぞれ の平均も算出した。Table2 より、包絡線の荷重は静的及び動的でほ ぼ同等の数值を示していることがわかる。しかし、静的に比べ動的 試験における荷重の方が多少大きい傾向は確認された。4 章ではこ の多少の差がエネルギー吸収量にどれ程の影響を与えるのかを検討 し、5 章では静的荷重に対する動的荷重の増分(以下荷重差と呼ぶ) が何に起因するのか検討する。

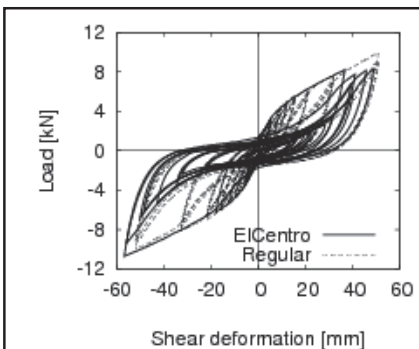

(a) EICentro

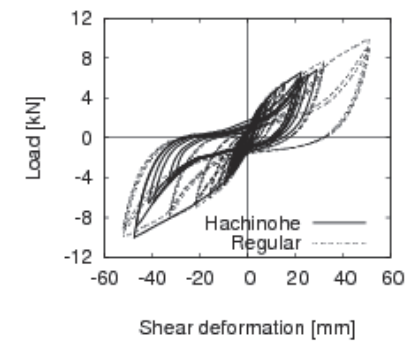

(c) Hachinohe

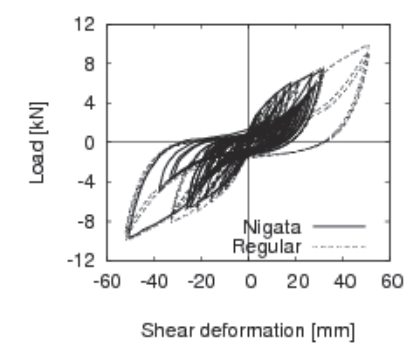

(e) Nigata

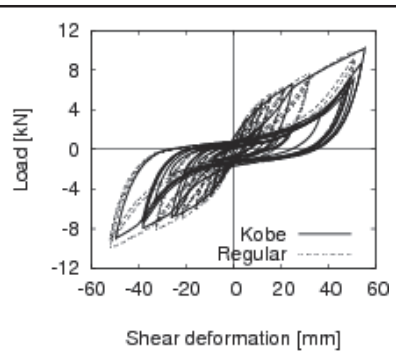

(b) Kobe

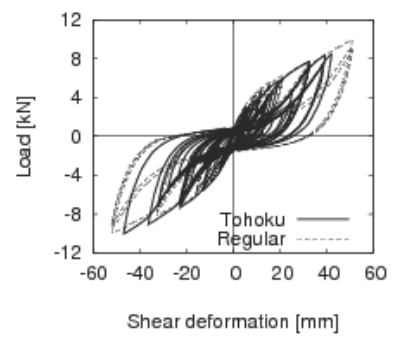

(d) Tohoku

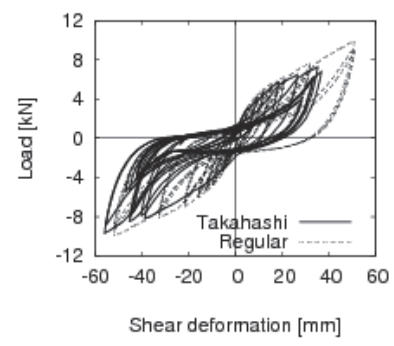

(f) Takahash
Fig. 6 Relation of $P \& x$ [random \& regular] of static

Table2 Load (kN) [dyn: dynamic sta: static]

\begin{tabular}{c||cc|cc|cc|cc|cc|cc|cc}
\hline \multirow{2}{*}{ Parameter } & \multicolumn{1}{|c|}{$1 / 450$} & \multicolumn{2}{c|}{$1 / 300$} & \multicolumn{2}{|c|}{$1 / 200$} & \multicolumn{2}{c|}{$1 / 150$} & \multicolumn{2}{|c|}{$1 / 100$} & \multicolumn{2}{|c}{$1 / 75$} & \multicolumn{2}{c}{$1 / 50$} \\
\cline { 2 - 14 } & dyn & sta & dyn & sta & dyn & sta & dyn & sta & dyn & sta & dyn & sta & dyn & sta \\
\hline \hline EICentro & 3.7 & 3.2 & 4.7 & 4.0 & 5.8 & 4.8 & 6.7 & 5.6 & 8.0 & 6.7 & 8.9 & 7.8 & 10.8 & 9.8 \\
Kobe & 3.4 & 3.2 & 4.1 & 4.0 & 5.2 & 5.0 & 6.0 & 5.7 & 7.1 & 6.9 & 8.2 & 7.7 & 9.8 & 9.9 \\
Hachinohe & 3.5 & 3.3 & 4.2 & 4.1 & 5.3 & 5.1 & 6.2 & 5.8 & 7.2 & 6.9 & 8.5 & 8.1 & - & - \\
Tohoku & 3.4 & 3.2 & 4.4 & 4.0 & 5.4 & 5.0 & 6.3 & 5.8 & 7.6 & 7.0 & 8.5 & 7.9 & - & - \\
Nigata & 3.3 & 3.1 & 4.2 & 3.9 & 5.4 & 4.7 & 6.5 & 5.5 & 8.1 & 6.6 & 8.9 & 7.6 & - & - \\
Takahashi & 3.5 & 3.0 & 4.3 & 3.7 & 5.3 & 4.5 & 6.0 & 5.2 & 7.3 & 6.3 & 8.1 & 7.3 & 10.0 & 9.2 \\
\hline Average & 3.5 & 3.2 & 4.3 & 4.0 & 5.4 & 4.9 & 6.3 & 5.6 & 7.6 & 6.7 & 8.5 & 7.7 & 10.2 & 9.6 \\
\hline Regular & - & 3.3 & - & 4.2 & - & 5.1 & - & 5.8 & - & 6.9 & - & 7.9 & - & 9.7 \\
\hline
\end{tabular}




\section{4. 動的と静的の総エネルギ一吸収量}

本章では動的及び静的載荷時の総エネルギー吸収量について検討 する。総エネルギー吸収量は Fig.5 の履歴曲線が描く総履歴面積 $W[W=P d x]$ として地震波毎に算出し Table3 に示した。動的載荷時の 総エネルギー吸収量は $v W$ 、静的載荷時の総エネルギー吸収量は $o W$ で表し、そのうち静的試験は地震波毎に 3 体行っているのでそれぞ れ $0 W_{1} 、 0 W_{2} 、 0 W_{3}$ とし、それら $0 W_{1} \sim 0 W_{3}$ の平均を 0 Wave とした。（） 内は静的に対する動的の総エネルギー吸収量の倍率 $\left[{ }^{2} W / 0 W\right]$ を示し ている。尚、検討域は 2.4 節の Fig. 4 に示した黒線部のみであるた め、一般的に考えられている総エネルギー吸収量よりも小さな值と なっている。Table3 より、vW/oW はどの地震波においても 1.0 以上 の值を示しているため総エネルギー吸収量は動的載荷時に増加する といえる。しかし Kobeにおいては他の地震波に比べ い結果となった。これは、Kobeの地震波の特徽により他の地震波と 異なるせん断抵抗状態になったためと考えられる。今後はこの挙動 に対する詳細な分析も必要であろう(本論では言及しない)。また Kobe を除く各地震波における $v W / o W$ ave $の$ 総平均を算出したところ 1.30 であった。したがって、動的載荷時の総エネルギー吸収量は静 的載荷時に対しおよそ 1.30 倍程度増加するといえる。

Table3 Energy absorption $W(\mathrm{kN} \cdot \mathrm{mm})$

\begin{tabular}{|c|c|c|c|c|c|}
\hline Parameter & ${ }{ }_{W}$ & $o W_{l}$ & $\mathrm{oW}_{2}$ & $o W_{3}$ & oWave \\
\hline EICentro & 2632 & $2128(1.24)$ & $1926(1.37)$ & $2026(1.30)$ & $2027(1.30)$ \\
\hline Kobe & 2165 & $1920(1.13)$ & $2044(1.06)$ & $2105(1.03)$ & $2023(1.07)$ \\
\hline Hach inohe & 1407 & $1183(1.19)$ & $1076(1.31)$ & $1140(1.23)$ & $1133(1.24)$ \\
\hline Tohoku & 2201 & $1814(1.21)$ & $1698(1.30)$ & $1711(1.29)$ & $1741(1.26)$ \\
\hline Nigata & 2100 & $1583(1.33)$ & $1618(1.30)$ & $1414(1.49)$ & $1538(1.37)$ \\
\hline Takahashi & 2421 & $1751(1.38)$ & $1814(1.32)$ & $1866(1.30)$ & $1819(1.33)$ \\
\hline \multicolumn{5}{|c|}{ Average of $\left[{ }^{v} W / 0\right.$ Wave $]$} & 1. 30 \\
\hline
\end{tabular}

\section{5. 荷重差と速度の関係}

本章では Fig.7 に示すような荷重変形曲線の同一変形時における 荷重の差 $\angle P\left[{ }_{v} P-0 P\right]$ に着目し、速度 $\dot{x}$ との関係について検討する。 荷重差 $\triangle P$ について Fig.7 に概要を示す。Fig.7 にはある変形時 $x_{n}$ のみについて示してある。また速度文は変位を時間で微分(中央差分, サンプリング周波数 $200 \mathrm{~Hz}$ ) することで算出した。そして Fig.8 に各 地震波における荷重差 $\angle P$ (縦軸) と速度 $\dot{x}$ (横軸)の関係を示した。各 地震波動的試験 1 体に対し静的試験は 3 体行っているためここでは そのうちの1つを示した。

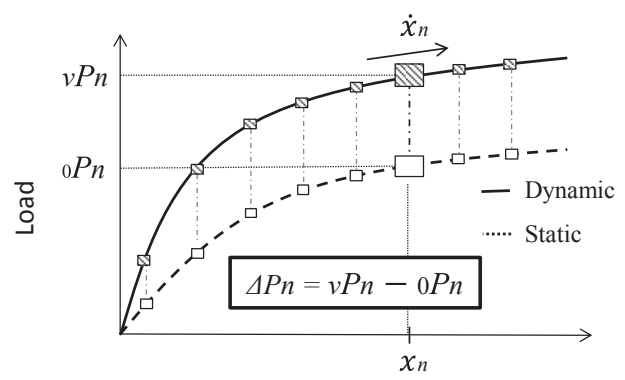

Shear deformation

Fig. 7 Summary about $\triangle P$

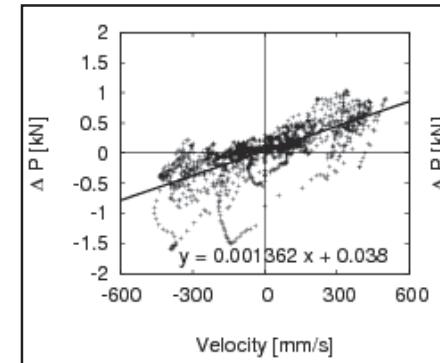

(a) EICentro

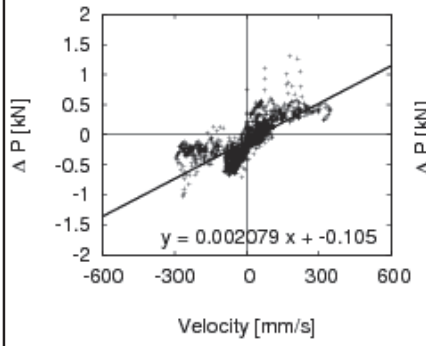

(c) Hachinohe

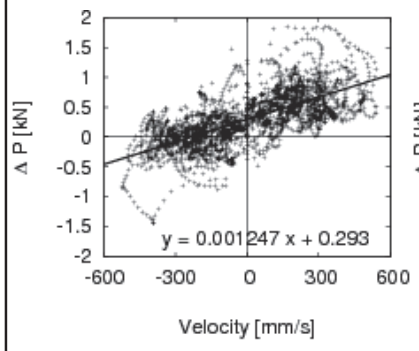

(e) Nigata

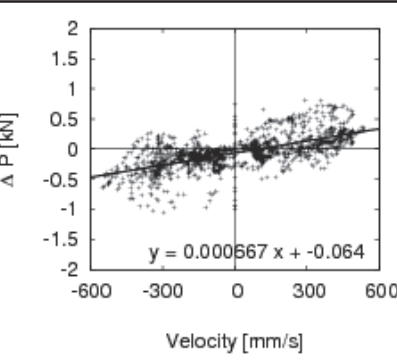

(b) Kobe

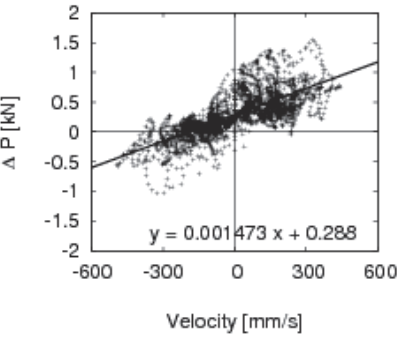

(d) Tohoku

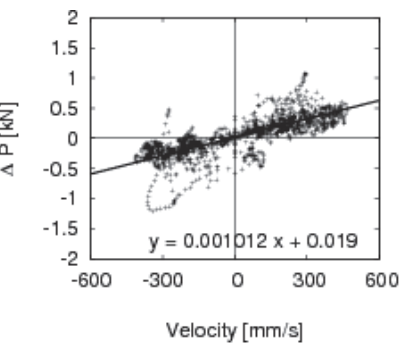

(f) Takahashi
Fig. 8 Relation of $\triangle P \& \dot{x}$

Fig.8 より、速度文が大きくなるにつれ荷重差 $\triangle P$ も大きくなる関 係がどの地震波においてもみられた。(c)Hachinohe をみると傾きは 複数存在するようにみえるが、多少強引に荷重差 $\angle P$ と速度 $\dot{x}$ の関係 を最小二乗法により線形 1 次式として算出し各図中太線で表示した。 さらに算出した式を各図中の下部に示した。

\section{6. 耐力壁の粘性減衰分を示す減衰係数}

\section{1 Voigt 型モデルの理論展開}

本節では耐力壁のせん断抵抗モデルをVoigt 型モデルとしてその 理論的展開を行い、試験結果から耐力壁の減衰係数を導く手法を示 す。力の釣り合い関係は弾塑性挙動を示寸式(1)のような形とした。

$$
M \angle \dot{x}+C_{i} \angle \dot{x}+K_{i} \angle x=\angle P
$$

$M$ は質量、 $C i$ は減衰係数、 $K i$ は瞬間剛性、 $P$ は荷重、 $x, \dot{x}, \ddot{x}$ は耐 力壁の挙動、 $\measuredangle$ は増分 $\left(\angle x=x_{i}-x_{i-l}\right)$ を示す。

この時、瞬間剛性 $K i$ は動的及び静的で変化がないものと仮定し、 静的に対する動的の変化分は全て減衰項 $C_{i} \angle \dot{x}$ で表すことにする。 ここで、式(1)から特定点 $n$ の荷重 $P_{n}$ を式(2)のようにして示す。

$$
\sum_{i=1}^{n} M \angle \ddot{x}+\sum_{i=1}^{n} C_{i} \angle \dot{x}+\sum_{i=1}^{n} K i \angle x=P_{n}
$$

ここで質量 $M$ は一定でまた減衰係数 $C i$ も一定と仮定すると式(2) は式(3)、そして式(4)となる。

$$
\begin{aligned}
& M \sum_{i=1}^{n} \angle \ddot{x}+C \sum_{i=1}^{n} \angle \dot{x}+\sum_{i=1}^{n} K i \angle x=P_{n} \\
& M \ddot{x}_{n}+C \dot{x}_{n}+\sum_{i=1}^{n} K i \angle x=P n
\end{aligned}
$$


式(4)を $[$ 内力 $($ 左辺)=外力 $($ 右辺)]の関係に整理する。(式(5))

$C \dot{x}_{n}+\sum_{i=1}^{n} K i \angle x=P_{n}-M \ddot{x}_{n}$

式(5)を動的試験 $\left(v P_{n}=P_{n}-M \ddot{x}_{n}\right)$ 及び静的試験 $(\ddot{x}=\dot{x}=0)$ の状態で表 すとそれぞれ式(6)式(7)となる。

$C \dot{x}_{n}+\sum_{i=1}^{n} K i \angle x={ }_{v} P_{n}$

$\sum_{i=1}^{n} K i \angle x=o P_{n}$

式(6)、式(7)から式(8)が得られる。

${ } P_{n}-o P_{n}=C \dot{x}_{n}$

式(8)の左辺 $\left[v P_{n}-o P_{n}\right]$ は同一変形時 $x_{n}$ における荷重差 $\triangle P$ を示す。 つまり 5 章の Fig.8 でみられた傾きは減衰係数 $C$ を示すことにな る。以上の概念を Fig.9 に示す。

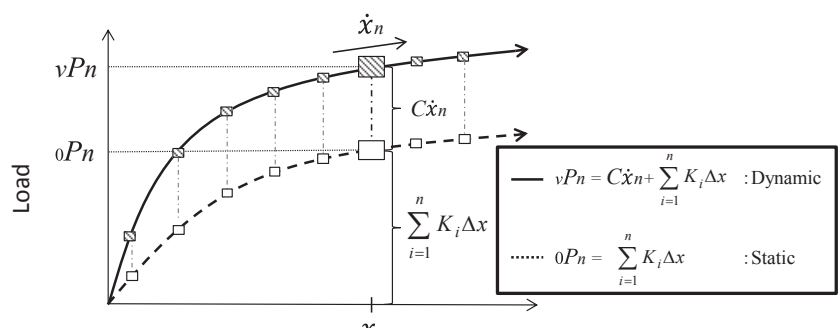

Shear deformation

Fig. 9 Summary about the formula (8)

\section{2 減衰係数の定量評価その 1}

式(8)を用い、Fig.8(荷重差速度関係)の傾きから減衰係数 $C$ を地震 波毎に算出した。地震波毎に 3 体の静的試験を行っており減衰係数 $C$ も地震波毎に 3 つ求められることになるため、それぞれを $C_{1} \sim C_{3}$ としさらにそれらの平均Caveを地震波毎に算出し Table4に示した。 Table4 より、減衰係数 $C$ は Kobe を除き大きく変化することはなか つた。Kobe を除き地震波の平均を算出すると $1410(\mathrm{~N} \cdot \mathrm{s} / \mathrm{m})$ であっ た。尚、この数值は耐力壁の幅 $910 \mathrm{~mm}$ での数值であることを断っ ておく。

\section{3 減衰係数の定量評価その 2}

本節では動的及び静的載荷時のエネルギー吸収量から簡易的に減 衰係数を算出することを試みる。ただし、本理論では動的及び静的 載荷での瞬間剛性は等しいと仮定しているため、動的及び静的載荷 での履歴減衰も等しくなるという仮定のもとでの検討である。前述 した式(8)(特定点 $n$ に限定しない)の各項を微小変位 $d x$ で積分する と式(9)が得られる。

$$
\int v P d x-\int 0 P d x=\int C \dot{x} d x
$$

左辺は動的及び静的載荷時の総エネルギー吸収量の差（ $\Delta W$ とす る)である。式(9)の概念を Fig.10 に示す。

ここで減衰係数 $C$ は一定と仮定しているため式(10)が得られる。

$$
\angle W=C \int \dot{x} d x
$$

さらに式(10)を変形し式(11)を得る。

$$
C=\Delta W / \int \dot{x} d x
$$

式(11)より $/ W$ 及び $\int \dot{x} d x$ を代入することで耐力壁の減衰係数 $C$ を算出することができる。 $\dot{x} d x$ は縦軸が速度、横軸が変形の速度変 形曲線が描く履歴面積である。
式(11)を用い減衰係数 $C$ を算出し Table5 に示した。6.2 節同様、 $C_{1} \sim C_{3}$ 及びそれらの平均 Cave も算出した。

Table5 より、減衰係数 $C$ は Table4 とわずかに異なる結果となっ た。これは、式(11)で求めた減衰係数 $C$ は数值を代入することで直 接的に求められることに対し、式(8)は最小二乗法による近似式によ り求めるため $\mathrm{y}$ 切片が 0 でないこと等が起因し、異なる結果になっ たと考えられる。それでも大局的に判断すると、式(11)によって求 めた耐力壁の減衰係数 $C$ は 6.2 節で求めた $C$ より簡易的に算出で き、かつほぼ同等の值であり、妥当性が認められるといえよう。

以上 6 章をまとめると、枠組壁工法耐力壁の時刻歴応答解析にお いては、静的載荷における復元力に、式(8)又は式(11)より算出した 減衰係数 $C$ を用いた減衰力 $C \dot{x}$ を付加することによってモデルを作 成することが可能であるといえよう。

Table4 Damping coefficient

\begin{tabular}{c||c|c|c|c}
\hline \multirow{2}{*}{ Parameter } & \multicolumn{4}{c}{ Damping coefficient (N $\cdot \mathrm{s} / \mathrm{m})$} \\
\cline { 2 - 5 } & $C_{1}$ & $C_{2}$ & $C_{3}$ & Cave \\
\hline \hline ElCentro & 1135 & 1561 & 1362 & 1353 \\
\hline Kobe & 667 & 397 & 522 & 529 \\
\hline Hachinohe & 1353 & 2079 & 1713 & 1715 \\
\hline Tohoku & 1229 & 1473 & 1470 & 1391 \\
\hline Nigata & 1293 & 1247 & 1631 & 1390 \\
\hline Takahashi & 1481 & 1103 & 1012 & 1199 \\
\hline \hline
\end{tabular}

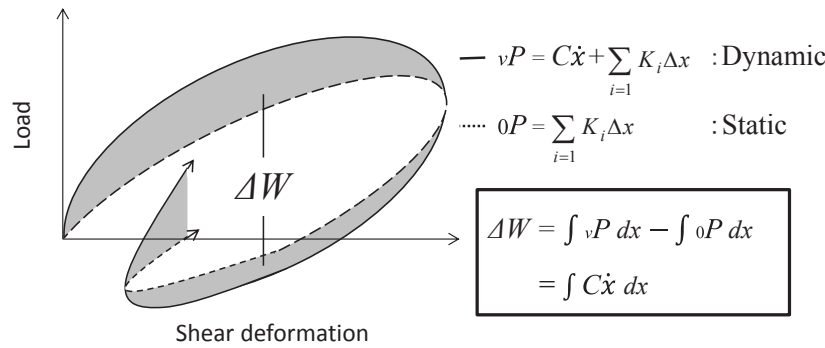

Fig. 10 Summary about the formula (10)

Table5 Damping coefficient 2

\begin{tabular}{c||c|c|c|c}
\hline \multirow{2}{*}{ Parameter } & \multicolumn{4}{c}{ Damping coefficient (N - s/m) } \\
\cline { 2 - 5 } & $C 1$ & $C 2$ & $C 3$ & Cave \\
\hline \hline ElCentro & 1197 & 1640 & 1420 & 1419 \\
\hline Kobe & 639 & 369 & 291 & 433 \\
\hline Hachinohe & 1486 & 2170 & 1766 & 1801 \\
\hline Tohoku & 1241 & 1564 & 1529 & 1444 \\
\hline Nigata & 1296 & 1220 & 1659 & 1392 \\
\hline Takahashi & 1477 & 1283 & 1226 & 1329 \\
\hline \hline
\end{tabular}




\section{7. 等価線形モデルで用いる減衰項の提言}

木質構造物の限界耐力計算での等価線形モデルにおける等価粘性 減衰定数は、建物全体として $20 \%$ 程度 ${ }^{10}$ )(様々な条件で変動する)与 える方法がとられているが、減衰は多くの因子が複雑に影響してい るため、その詳細については不明確な点が多い。ただし、因子の一 つとして考えられている履歴減衰については、部材毎(耐力壁単体を 含む)に数值を与えることで、ある程度予測が可能となっている 11)(Fig.11\}参照)。しかしながらその他の因子については現状として 予測が困難な状況にある。そこで本節では 6 章で算出した耐力壁の 減衰係数から等価線形モデルにおける粘性減衰分の等価粘性減衰定 数を評価することを試みる。さらにそれを履歴減衰分の等価粘性減 衰定数に付加することで(Fig.12)、等価線形モデルで耐力壁が保有 する減衰性能を明らかにする。ただし本検討では建築基準法が要求 する壁量のみを保有する建物を想定する。以下にその手法を記す。

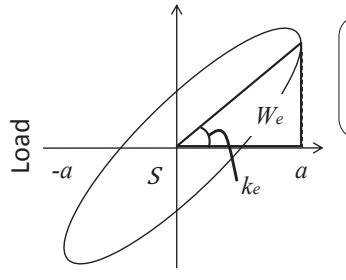

Shear deformation

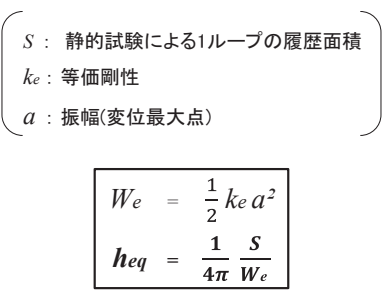

Fig. 11 Equivalent I inearization

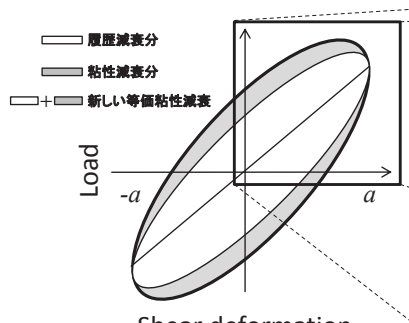

Shear deformation

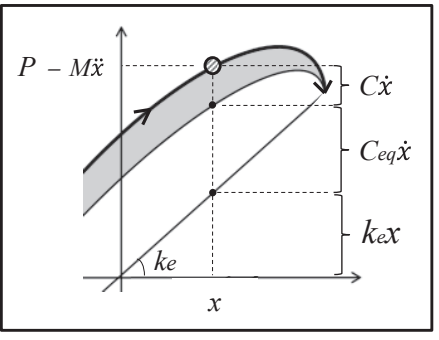

Fig. 12 New equivalent I inearization

履歴減衰分を示す等価粘性減衰定数 $h e q$ (Fig.11 参照)を式(12)より 等価粘性減衰係数 $C e q$ に変換する。

$$
C_{e q}=2 h_{e q} \sqrt{M k e}
$$

式(12)を用い、等価線形モデルの運動方程式を式(13)に表す。

$M \ddot{x}+C_{e q} \dot{x}+k_{e} x=P$

式(13)に粘性減衰分を付加すると式(14)となる。

$M \ddot{x}+C \dot{x}+C_{e q} \dot{x}+k_{e} x=P$

$(C \dot{x}$ : 粘性減衰 $C e q \dot{x}$ : 履歴減衰 $k e x$ : 等価剛性による弾性力 $)$ まとめると式(15)となる。

$M \ddot{x}+(C+C e q) \dot{x}+k e x=P$

式(15)の $C+C_{e q}$ を ${ }_{n e w} C e q$ と置き、新しい等価線形モデルとして式 (16)に示す。

$$
M \ddot{x}+{ }_{n e w} C_{e q} \dot{x}+k e x=P
$$

またその時の等価粘性減衰定数 newheq を式(17)より算出する。

newheq $={ }_{\text {new }} C_{\text {eq }} 2 \sqrt{M k e}$

newheq 及び履歴減衰分を示す等価粘性減衰定数 heq、それらの差 [newheq -heq、これは粘性減衰分を示す( ${ }_{\text {vheq }}$ とする)]を Table6 に示し た。上記を求めるために必要な減衰係数 $C$ は 6.3 節より $1477(\mathrm{~N}$ ・ $\mathrm{s} / \mathrm{m})$ とし、質量 $M$ は式(18)より $2800 \mathrm{~kg}$ 、 $k e$ 及び heq は、規則繰り返 し載荷における $1 / 50(\mathrm{rad})$ 時の 3 サイクルの平均值を用いた。

$$
M=P_{0} / g C_{0}
$$

$\left(P_{0}\right.$ : 許容耐力 $g:$ 重力加速度 $C_{0}:$ :地震層せん断力係数 0.2$)$

Table6 New equivalent viscous damping factor

\begin{tabular}{c|c|c}
\hline newheq $(\%)$ & Heq $(\%)$ & vheq $(\%)$ \\
\hline 14.9 & 11.5 & 3.4 \\
\hline
\end{tabular}

\section{8. まとめ}

本論による枠組壁工法耐力壁 $(910 \mathrm{~mm})$ の動的不規則荷重下にお ける面内せん断性状及び減衰係数を以下にまとめる。ただし最大忘 答変形角 $1 / 50 \mathrm{rad}$ 程度を想定する場合であることを断っておく。

・動的加力時における耐力壁のエネルギー吸収量は静的加力時に対 し 1.30 倍程度増加する。(4 章)

・動的及び静的の同一変形時における荷重の差はその時の速度によ って変化する。速度が大きいほど荷重差も大きくなる。（5 章）

・耐力壁の力学モデルを Voigt 型モデルで表すと荷重差の速度変化 は粘性減衰力によるものとして評価できる。粘性減衰分の減衰係 数はおよそ $1477(\mathrm{~N} \cdot \mathrm{s} / \mathrm{m})$ である。（6 章)

・耐力壁の等価線形モデルにおける等価粘性減衰定数は粘性減衰分 が $3 \%$ 程度、履歴減衰分が $12 \%$ 程度の割合を占めている。ただし 想定する建物は、建築基準法が要求する最低限の壁量を保有する 建物である。（7 章 $)$

\section{謝辞}

本研究の実験に際し明治大学理工学部建築学科木質構造研究室に 在籍していた荒美貴宏氏をはじめとする学生の皆様に多大なるご協 力を頂きました。また論文作成に際し同研究室 OB 多大なるご指導を頂きました。ここに謝意を表します。

\section{参考文献}

1)性能規定型耐震設計-現状と課題,日本地震工学会,鹿島出版会,2006.6. 2)建築物の減衰 $<$ 第 1 版 $>$, 日本建築学会, 2000 . 3)西村彰敏,鈴木修三,林崎正伸,宮澤健二:木質構造の動的性能に関寸る研究そ の 7, 日本建築学会大会学術講演梗概集, C-1, 構造III,pp95-96,2003.9 4)綿引誠,町田健一,大橋好光: 各種耐力壁による静的・動的加力試験その 6 , 日 本建築学会大会学術講演梗概集,C-1,構造III,pp445-446,2004.8

5)山口修由,箕輪親宏:木質構造の耐震性能評価に与える変形速度と繰り返し 加力の影響,構造工学論文集,Vol.52B,pp447-456,2006.3

6)梶川久光,三津橋歩,高木良,小川春彦,六車典子,野口弘行:木質系実大耐力壁 面の動的挙動に関する研究その 5 , 日本建築学会大会学術講演梗概集,C- 1 , 構 造III,pp457-458,2008.9

7)内山善明,野口弘行,鈴木秀三:木質面材釷打ち耐力壁の等速度加力下におけ るせん断性状変化に関する研究,日本建築学会構造系論文集,第 74 巻,第 636 号,pp313-319,2009.2

8)金子大希,野口弘行,内山善明:木質系耐力壁形式構造物のせん断性状に及ぼ 寸荷重速度の影響について第 10 報, 日本建築学会大会学術講演梗概集, C- 1 , 構造吕,pp21-22,2014.9

9)2007 年枠組壁工法建築物構造計算指針,社団法人ツーバイフォー建築協 会,2007.11

10)建築物荷重指針・同解説,日本建築学会,2004.

11)柴田明徳:最新耐震構造解析 $<$ 第 2 版 $>$,森北出版株式会社,2004. 


\section{STUDY ON SHEAR PROPERTIES AND DAMPING COEFFICIENT OF \\ WOODEN BEARING WALL IN DYNAMIC RANDOM LOAD ASSUMING SEISMIC MOTION}

\section{Daiki KANEKO* and Hiroyuki NOGUCHI**}

\footnotetext{
* Grad. Stud., Dept. of Architecture, Graduate School of Science Technology, Meiji Univ.
}

** Prof., Dept. of Architecture, School of Science and Technology, Meiji Univ., Dr. Eng.

The purpose of this study is to clarify the in-plane shear performance and to evaluate the damping coefficient of the wooden bearing wall under the dynamic random load.

In 2009, Long-term quality housing certification system is introduced, also on the seismic performance design method in wood structure housing is adapted to be required. The method, it is necessary to predict the response value of the structures, are recommended to be used, such as time history calculation and limit strength calculated in the structural calculations. Therefore dynamic performance of the structure calculation is reflected strongly on dynamic performance, it is important to understand the dynamic performance finely wood structure. The dynamic performance of the general structure is often evaluated as damping performance. Therefore, accurately evaluate the damping performance in wood structures have become important.

Common with the structure of the wood structure housing is often using a wooden bearing wall. Therefore revealing the dynamic shear properties and damping performance of the bearing wall is important. For research on them has left a lot of achievements by performing a tension loading tests and regularly repeated loading tests using the wooden bearing wall.

But their evaluation is an evaluation of all tension loading test and regularly repeated loading tests evaluation is not performed based on dynamic and static random loading tests assuming the actual behavior called seismic. The authors think that the dynamic shear performance and damping performance when subjected to such a loading test is also important. Therefore, by performing dynamic and static tests that assume seismic, to elucidate the dynamic random shear performance of the wooden bearing wall and evaluate damping coefficients.

Results are shown in the following.

1) Energy absorption amount at the time of dynamic motion was increased 1.30 times than static motion.

2) The load at the time of the same deformation was increased during dynamic behavior than in the static behavior.

The increased amount has grown faster velocity at that time.

3) Damping coefficient of the wooden bearing wall is about $1477(\mathrm{~N} \cdot \mathrm{s} / \mathrm{m})$.

4) Equivalent viscous damping factor in the equivalent linearization method of the wooden bearing wall is about $15 \%$. ( viscous damping factor is about $3 \%$ and hysteresis damping factor is $12 \%$ )

From the above, it is revealed shear properties and damping coefficient of the wooden bearing wall under dynamic random load. 